\title{
O IMPERIALISMO SEDUTOR: A AMERICANIZAÇÃO DO BRASIL NA ÉPOCA DA SEGUNDA GUERRA
}

\author{
de Antonio Pedro Tota \\ São Paulo : Companhia das Letras, 2000. 235 p. \\ por Ana Cristina Braga Martes, Professora de \\ Sociologia da FGV-EAESP. \\ E-mail: acbmartes@fgvsp.br
}

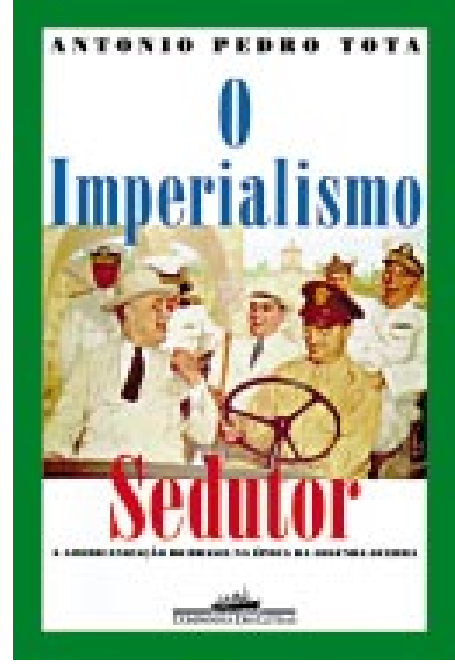

$\mathrm{S}$ eiscentos mil brasileiros vivem, atualmente, como imigrantes nos Estados Unidos. Lá eles trabalham, criam os filhos e tentam, de algum modo, usufruir do "sonho americano". Os fatores de atração dessa população não se restringem à esfera econômica. Muitos brasileiros são atraídos por um antigo fascínio que a sociedade norte-americana exerce sobre o Brasil. A emigração brasileira pode significar o fechamento de um círculo, o resultado de um certo "jogo de sedução" que envolveu os dois países a partir dos anos 40 , sendo o Brasil, obviamente, o parceiro mais frágil do jogo.

O livro $O$ imperialismo sedutor, de Antonio Tota, professor de História da PUC (SP), analisa o processo de americanização do Brasil, um tema que é, talvez mais do que nunca, oportuno. O livro, baseado em pesquisas de arquivos brasileiros e norte-americanos, é acessível ao grande público; sua leitura, agradável.

Os artifícios empregados nessa "conquista" bem-sucedida foram os meios de comunicação, particularmente o rádio e o cinema, usados como parte da denominada Política de Boa Vizinhança desenvolvida durante o governo Roosevelt. Sob a ameaça da conquista dos trópicos pelos nazistas, tentou-se atrair a simpatia pelo estilo de vida norte-americano, estratégia mais segura e eficaz do que a ameaça aberta de intervenção bélica. Nesse jogo, os norte-americanos elogiaram nosso café, nossa música e Carmen Miranda. Paramos de olhar para a Europa e passamos a admirar o progresso norte-americano, seu cinema, a indústria de gadgets, seu "moderno" estilo de vida.
Tal estratégia foi capitaneada pelo milionário norte-americano Nelson Rockefeller, proprietário, entre outros bens, da Standard Oil. Preocupado com os empreendimentos norte-americanos na América Latina, especialmente no Brasil, Rockefeller acreditava que o sucesso dessas empresas dependia não apenas da venda de seus produtos por aqui mas também da simpatia pelos Estados Unidos e seus valores liberais democráticos.

Para dar seguimento ao plano de sedução, foi criado o Office of the Coordinator of InterAmerican Affairs (OCIAA), dirigido por Nelson Rockefeller. O órgão funcionou, segundo Tota, como uma "verdadeira fábrica de ideologia", orquestrando a produção de empatias recíprocas na área de comunicação e informação. A Divisão de Cinema do OCIAA conquistou tanto Walt Disney quanto Carmen Miranda para a "causa da liberdade nas Américas" e tinha como missão promover a produção de filmes e cinejornais sobre os Estados Unidos e "outras Américas" (como éramos chamados) e combater o cinema produzido pelo Eixo. Por seu intermédio, Walt Disney colocou sua tropa (Pato Donald, Mickey e companhia) na campanha do esforço de guerra, e Darryl Zanuck produziu o primeiro filme de Carmen Miranda que, na época, foi capaz de "tirar a $20^{\text {th }}$ Century Fox do vermelho".

As empresas de Hollywood não tardaram a conquistar o dócil mercado brasileiro, contando, para isso, com o apoio de mitos do cinema norte-americano como Orson Welles. O diretor de "Cidadão 
Kane" foi chamado a produzir um filme sobre a América Latina. Imbuído dessa nobre missão, desembarcou no Rio de Janeiro em 1942, como um dos embaixadores do Pan-americanismo.

Com a chegada ao Brasil de astros de Hollywood, entre eles o próprio Walt Disney, garantimos também nossa presença, sem dúvida muito mais modesta, nos Estados Unidos. Participamos da Feira Internacional de Nova York (1939), exibindo nossas riquezas naturais e artísticas, sob a batuta de Romeu Silva, e a música de Ernesto Nazareth, no pavilhão do Brasil, projetado por Oscar Niemeyer. O Museu de Arte Moderna de Nova York promoveu, em 1940, o Festival of Brazilian Music irradiado pela NBC para todos os Estados Unidos. Ary Barroso foi tão popular no Brasil quanto naquele país, após a "Aquarela do Brasil" ter sido cantada no filme "Alô Amigos" de Walt Disney.

Justamente durante a ditadura do Estado Novo - período da História do Brasil mais associado aos modelos totalitários europeus -, nasceu e disseminou-se a influência norte-americana por aqui. O Departamento de Imprensa e Propaganda (DIP) colaborou estreitamente com o OCIAA, chegando a ceder parte do tempo do programa a Voz do Brasil para divulgar notícias sobre a guerra e os Estados Unidos.

Segundo Tota, "o fetiche dos gadgets, os filmes de Hollywood atuaram como tropa de vanguarda que prepara uma invasão". A difusão entre nós do espírito norte-americano (elogio ao progresso técnico e material) ocorreu justamente durante a guerra, que abriu a oportunidade de alardear o sucesso e a "superioridade" da industrialização norte-americana. Tais idéias foram veiculadas nos programas de rádio produzidos nos Estados Unidos e divulgados na América Latina com apoio do DIP, no caso do Brasil - na tentativa de atrair nossa simpatia.

Mas a entrada dos Estados Unidos no Brasil não foi uma via de mão única. Vargas também tirou proveito da Política de Boa Vizinhança para divulgar naquele país uma imagem positiva do Brasil e, especialmente, de nossos produtos, como o café. O governo brasileiro chegou a patrocinar noticiários de rádio para falar do nosso manganês, quartzo, aço, reserva de ferro, indispensáveis à vitória contra o Eixo. Os Estados Unidos precisavam de nossa matéria-prima. $\mathrm{O}$ Brasil precisava dos produtos manufaturados norte-americanos. Justificava-se, assim, a cooperação, cujo objetivo era impedir a expansão do nazismo sobre o continente. Os programas de rádio que veiculavam a Política de Boa Vizinhança faziam referências diretas a essa solidariedade: "sempre que você tomar um café brasileiro, você estará comprando a Política de Boa Vizinhança", repetiam os comentaristas do noticiário "News of the World", em 1940.

Segundo Tota, os "meios de comunicação imperialistas" não devem ser responsabilizados por uma "inoculação sorrateira de culturas estranhas em nosso meio". A mídia foi usada como instrumento pedagógico para americanizar o Brasil, o que comprova a existência de um plano articulado para promover a americanização. Esse projeto estava, contudo, imbricado às forças de mercado, e não apenas à política de Estado, ou seja, o mercado foi um dos caminhos percorridos para a americanização. Entretanto a assimilação cultural se fez não por pura imitação, mas por recriação, seguindo a antiga tendência de antropofagia na cultura brasileira.

Finalizando, vale a pena destacar a epígrafe de um dos capítulos do livro. Trata-se da entrevista com uma brasileira que, ao vencer o "Concurso Eugin" em 1940, declarou: "desde pequena imaginava-me a bordo de um grande transatlântico a rumar para o país dos arranha-céus. O cinema só fez aumentar o meu desejo." De lá para cá, muita coisa mudou. No lugar do transatlântico, os brasileiros sonham com um avião, e São Paulo, que, certamente, tem mais arranha-céus do que a maioria das metrópoles norte-americanas, perdeu a capacidade de atrair nossa população migrante. Contudo, o cinema norte-americano e os demais meios de comunicação ainda são capazes de atrair para aquele país centenas de milhares de brasileiros. Agora mais do que nunca! $\bigcirc$ 